\title{
Privatizing Personalized Law
}

\author{
Andrew Verstein $\dagger$
}

In recent years, scholars have devoted increasing attention to the prospect of personalized law. The bulk of the literature has so far concerned whether to personalize any law and, if so, what substantive changes should be instantiated through personalization. Comparatively little discussion has gone to the authorship of personalized laws. Who will make personalized laws? Who will enforce them? In this Essay, I propose we consider the who in the personalization debate. Specifically, I identify the policy considerations that bear on the optimal maker or enforcer of personalized law. To put it another way, my Essay begins where most of the prior literature leaves off: having concluded that personalized law has some merit in a given area, I ask when the state should facilitate personalized lawmaking by nonstate actors.

While there are many threads in the discussion, one theme emerges: the move to personalized law is often best taken by private lawmakers. Thus, as both a descriptive and normative matter, a future that makes the best use of personalized law should involve a diminished role for state directives.

\section{INTRODUCTION}

In recent years, scholars have devoted increasing attention to the prospect of personalized law. The bulk of the literature has so far concerned whether to personalize any law ${ }^{1}$ and, if so,

$\dagger$ Associate Professor of Law, Wake Forest University School of Law. JD, Yale Law School. I am grateful to all participants in The University of Chicago Law Review Symposium on Personalized Law for comments, but especially to Omri Ben-Shahar for insightful conversations.

1 See generally, for example, Omri Ben-Shahar and Ariel Porat, Personalizing Mandatory Rules in Contract Law, 86 U Chi L Rev 255 (2019) (arguing that personalized consumer contracts produce more efficient outcomes); Gerhard Wagner and Horst Eidenmüller, Down by Algorithms? Siphoning Rents, Exploiting Biases, and Shaping Preferences: Regulating the Dark Side of Personalized Transactions, 86 U Chi L Rev 581 (2019) (examining possible negative effects of personalization on business-to-consumer transactions); Oren Bar-Gill, Algorithmic Price Discrimination When Demand Is a Function of Both Preferences and (Mis)perceptions, 86 U Chi L Rev 217 (2019) (examining the costs, benefits, and possible responses to data-driven price discrimination); Matthew B. Kugler and Lior Jacob Strahilevitz, Assessing the Empirical Upside of Personalized Criminal Procedure, 86 U Chi L Rev 489 (2019) (examining the potential benefits of personalizing criminal procedure); Deborah W. Denno, Neuroscience and the Personalization of Criminal Law, 86 U Chi L Rev 359 (2019) (arguing that using neuroscientific evidence to evaluate defendants' mental culpability can personalize criminal law). 
what substantive changes should be instantiated through personalization. ${ }^{2}$

Comparatively little discussion has gone to the authorship of personalized laws. Who will make personalized laws?3 ${ }^{3}$ Who will enforce them?' ${ }^{4}$ The little attention directed to this question has assumed a somewhat conventional public/private dichotomy. Some papers have focused on ways in which the state could personalize its directives to citizens. ${ }^{5}$ Other work has focused on how personalization might help contracting parties better vindicate their objectives. ${ }^{6}$ In these latter papers, the only question for the

2 See, for example, Adi Libson and Gideon Parchomovsky, Toward the Personalization of Copyright Law, 86 U Chi L Rev 527, 542-46 (2019) (suggesting ways to personalize copyright law based on personalized consumption data); Christoph Busch, Implementing Personalized Law: Personalized Disclosures in Consumer Law and Data Privacy Law, 86 U Chi L Rev 309, 324-30 (2019) (suggesting potential elements for a personalized regulatory design for consumer law and data privacy law).

3 Within this Symposium, an exception is Professor Lee Fennell's contribution, which considers the possibility of self-authored law. See Lee Anne Fennell, Personalizing Precommitment, 86 U Chi L Rev 433, 447-56 (2019).

4 Within this Symposium, one exception may be Professor Dan L. Burk's contribution, focusing on how content owners will monitor and challenge arguable infringement in ways that erode fair use exceptions. See Dan L. Burk, Algorithmic Fair Use, 86 U Chi L Rev 283, 290-94 (2019). Although the tasks of enforcement and lawmaking can be combined in the same body, they are distinct tasks. Compare A.C. Pritchard, Markets as Monitors: A Proposal to Replace Class Actions with Exchanges as Securities Fraud Enforcers, 85 Va L Rev 925, 965-66 (1999) (emphasizing the enforcement function of trading markets), with Paul G. Mahoney, The Exchange as Regulator, 83 Va L Rev 1453, 1457-62 (1997) (emphasizing trading markets' rulemaking function). See also Stavros Gadinis and Howell E. Jackson, Markets as Regulators: A Survey, 80 S Cal L Rev 1239, 1246-48 (2007) (distinguishing among rulemaking, monitoring, and enforcement). I do not emphasize the monitoring function here because that function is not obviously amenable to personalization, at least not apart from the enforcement function.

5 See, for example, Cass R. Sunstein, Deciding by Default, 162 U Pa L Rev 1, 30-36 (2013) (focusing discussion on possible default rules public sector regulators and judges could adopt); Ariel Porat and Lior Jacob Strahilevitz, Personalizing Default Rules and Disclosure with Big Data, 112 Mich L Rev 1417, 1441-50 (2014) (suggesting applications of personalization to various areas of law); Anthony J. Casey and Anthony Niblett, The Death of Rules and Standards, 92 Ind L J 1401, 1410-11 (2017) (discussing how technological developments could facilitate personalized microdirectives); Omri Ben-Shahar and Ariel Porat, Personalizing Negligence Law, 91 NYU L Rev 627, 676-79 (2016) (proposing procedures by which courts could implement personalization, including gradually personalizing the law and making presumptions to fill gaps in data).

6 See, for example, Andrew Verstein, Ex Tempore Contracting, 55 Wm \& Mary L Rev 1869, 1896-1915 (2014) (describing institutions that provide personalized, transactionspecific guidance on legal obligations in construction contracts and financial derivatives); Porat and Strahilevitz, 112 Mich L Rev at 1441-42 (cited in note 5) (describing how personalized default rules might affect consumer contracts); Anthony J. Casey and Anthony Niblett, Self-Driving Contracts, 43 J Corp L 1, 9 (2017) (explaining how microdirectives provide parties with greater certainty about their contractual obligations). But see George S. Geis, An Experiment in the Optimal Precision of Contract Default Rules, 80 
state is whether to tolerate these arrangements as ordinary contractual provisions.

Yet law arises in settings other than state-centered public law and atomistic bilateral contracts. Private industry associations, such as diamond dealers, draft their own rules, adjudicate them in their own tribunals, and enforce them through nonlegal sanctions. ${ }^{7}$ Sports leagues do the same thing. ${ }^{8}$ Self-regulating organizations, such as the Financial Industry Regulatory Authority, regulate market professionals. So do stock exchanges, which also impose rules on corporate issuers. One of the great advances in legal scholarship in the last thirty years has been renewed focus on private ordering and lawmaking institutions, yet personalized law has yet to make this turn.

In this Essay, I propose we consider the who in the personalization debate. Specifically, I identify the policy considerations that bear on the optimal maker or enforcer of personalized law. To put it another way, my Essay begins where most of the prior literature leaves off: having concluded that personalized law has some merit in a given area, I ask when the state should facilitate personalized lawmaking by nonstate actors.

The Essay proceeds as follows: Part I briefly summarizes many of the lessons from the law personalization literature. I identify the factors that militate in favor of or against personalization of a given directive. In Part II, I turn to the question of private law generally. Quite apart from personalization, a vast literature analyzes the question of the optimal lawmaker. In Part III, I analyze these two literatures-personalization and privatization-in tandem to explore whether there are any lessons that arise from the interaction of these two agendas. In the Conclusion, I briefly consider the menu of options for state actors to effectuate private regulation when it is appropriate.

One word of clarification is that I use the words "law" and "lawmaker" quite generally here. The drafter of a contract is a

Tulane L Rev 1109, 1129-59 (2006) (arguing that simpler, generalized default rules are less costly and therefore preferable in contract law); Ian Ayers and Robert Gertner, Filling Gaps in Incomplete Contracts: An Economic Theory of Default Rules, 99 Yale L J 87, 91-93, 117-18 (1989) (providing "a general theory of . . . how [to] choose between tailored and untailored default rules").

7 See Lisa Bernstein, Opting out of the Legal System: Extralegal Contractual Relations in the Diamond Industry, 21 J Legal Stud 115, 132-35 (1992).

8 See Robert C. Ellickson, When Civil Society Uses an Iron Fist: The Roles of Private Associations in Rulemaking and Adjudication, 18 Am L \& Econ Rev 235, 248-49, 257-61 (2016). 
lawmaker for my purposes because she creates directives for her counterparty. A boss directing an employee is also a lawmaker even though an insubordinate employee could ignore the order.

\section{WHEN SHOULD THE LAW PERSONALIZE?}

Speed limits constrain the lawful driving speed for a given stretch of road. They are impersonal directives in that they apply to every driver equally. There is no exemption that permits highly competent drivers, or those with very important meetings, to exceed the posted speed limit.

Other constraints involve a measure of personalization. Position limits in commodities markets can provide such an example. Position limits constrain the amount of commodities futures that a single trader can own at a given time. Position limits are prophylactics against market abuse: if no one can own very much of any one asset, no one will have much power to disrupt the market. ${ }^{9}$

At their furthest points, position limits are impersonal, just like speed limits: exchange rules limit a trader of live cattle futures to something like 450 contracts of 40,000 pounds each, or $18,000,000$ pounds. ${ }^{10}$ For futures on the Russel 2000 Stock Index, the current limit is around 100,000 units. ${ }^{11}$

Yet position limits are personalized over much of their range. The right to even approach the hard ceiling of the position limit is constrained by a trader's identity and agenda, as well as market conditions. Below the hard ceiling of the position limit, exchanges create "position accountability levels" as presumptive ceilings. ${ }^{12}$ Anyone who reaches these levels must stop increasing their position until the exchange can solicit more information about "the nature and size of the position, the trading strategy

9 In the Matter of McVean Trading \& Investments, LLC, CFTC No 17-15, Comm Fut L Rptr (CCH) I 34,057 (available on Westlaw at 2017 WL 2929416) (using a positionlimits violation as the linchpin of a manipulation case).

10 Several factors impact the position limit. For example, as the contract approaches delivery date, the limit lowers. For live cattle, it drops to three hundred contracts. Likewise, some contract levels vary according to market conditions, rising or lowering as a function of deliverable supply. See, for example, Saberi v Commodity Futures Trading Commission, 488 F3d 1207, 1210-13 (9th Cir 2007) (describing the CME's position limit for pork belly futures contracts as "a function of both the total deliverable supply of frozen pork bellies and the time left until the expiration of the futures contracts," and citing CME Rule 8302.E(4), which defined deliverable supply as "the number of registered deliverable pork bellies reported in the CME Clearing House Department's weekly report immediately preceding the first Friday of each expiring contract month").

11 CME Position Limits (CME Group), archived at http://perma.cc/L57L-KDH5.

12 The accountability and position levels vary by commodity contract. 
employed with respect to the position, and hedging information, if applicable."13 After this, the trader may be permitted to continue to grow her position, or the trader may be instructed to reduce it. For example, Chicago Board of Trade treasury bond futures have an accountability level of $\$ 1$ billion. ${ }^{14}$ Thus, a trader who acquires a $\$ 1$ billion notional position must stop buying futures until she receives a personalized instruction from the exchange. Only at much higher levels, thirty thousand contracts or $\$ 3$ billion, do uniform limits on ownership arrive to constrain all traders equally. ${ }^{15}$ Implicit in this stepping up is that certain traders have legitimate rights to trade at higher limits than others-a personalized law.

In addition to exchange-made limits, Congress has instructed the Commodity Futures Trading Commission (CFTC) to craft its own position limits so as to "permit producers, purchasers, sellers, middlemen, and users of a commodity or a product derived therefrom to hedge their legitimate anticipated business needs for that period of time into the future for which an appropriate futures contract is open and available on an exchange." 16 The Commission is supposed to pay special attention to the largest hedgers in order "to prevent unwarranted price pressures by large hedgers." 17 The bona fide hedging exemption is supposed to cover hedging that "is economically appropriate to the reduction of risks in the conduct and management of a commercial enterprise" 18 or arises from potential changes in value in commodities or services one owns, owes, or will soon own or owe. ${ }^{19}$ Also, one may hedge the risk of being counterparty to a bona fide hedger. ${ }^{20}$

Speed limits are impersonal. Position limits admit of personalization. What factors should inform the optimal degree of personalization of a given area of law? Summarizing the literature, I

13 Market Regulation Advisory Notice RA1711-5*2 (CME Group, 2017), archived at http://perma.cc/96X4-LZ82.

14 Or ten thousand contracts. CBOT Position Limits (CME Group), archived at http://perma.cc/PZL6-LTXD. The contract size for one US Treasury bond future is $\$ 100,000$. U.S. Treasury Bond Futures Contract Specs (CME Group, 2018), archived at http://perma.cc/WK4M-FEQY.

15 On the distinction between position limits, position accountability levels, and exemptions, see Market Regulation Advisory Notice RA1518-5R *1-2 (CME Group, 2015), archived at http://perma.cc/CV5Y-JRER.
167 USC $\S 6 \mathrm{a}(\mathrm{c})(1)$.
177 USC $\S 6 \mathrm{a}(\mathrm{c})(1)$.
187 USC $\S 6 a(c)(2)(A)(i i)$.
19 See 7 USC $\S 6 a(c)(2)(A)(i i i)(I I I)$.
20 See 7 USC $\S 6 a(c)(2)(B)(i)-(i i)$. 
suggest that there are three broad considerations relevant to the personalization question, each of which is decided by several factual and normative considerations. I briefly summarize these claims below.

\section{A. Formal Equality}

Impersonal law treats all subjects formally alike. By addressing all subjects equally, an impersonal law may affirm common membership in a community. Addressing some individuals differently may emphasize or reify their differences. For example, a law that changes women's names by default upon marriage may subordinate women as a group, encourage stereotypes about what women want, or penalize women who differ from the norm. Impersonal law - a law that switches names for everyone or no oneavoids this problem. ${ }^{21}$

Yet formal equality can result in substantive inequality if individuals have different needs and capacities. A tort law requiring the same actions of everyone could treat blind people too roughly, because they may be unable to comply with some directives, and skilled people too gently, because they could easily improve their compliance above the typical level. ${ }^{22}$

A closely related observation is that formal equality often entails cross-subsidies. These cross-subsidies can help the least powerful or sophisticated subjects. If a single law must accommodate all subjects, then the lawmaker must make a law that is acceptable to powerful members of the subject group. Vulnerable individuals may be able to free ride off of those rules; ${ }^{23}$ left on their own to bargain in contract or lobby for good treatment, it is possible that vulnerable subjects might make mistakes or lack the power to obtain good terms. For example, it is now easy and cheap

21 See Ian Ayres, Regulating Opt-Out: An Economic Theory of Altering Rules, 121 Yale L J 2032, 2111-13 (2012) (describing how tailoring default rules for different types of parties can be discriminatory); Elizabeth F. Emens, Changing Name Changing: Framing Rules and the Future of Marital Names, 74 U Chi L Rev 761, 827-39 (2007) (discussing different possible marital name defaults).

22 See Ben-Shahar and Porat, 91 NYU L Rev at 637-42 (cited in note 5) (describing how tort law treats both those with diminished and elevated capacities).

23 Vulnerability is used here as a relative rather than absolute concept. For example, the absence of retroactive taxes is supported by a coalition of property owners. Saul Levmore, The Case for Retroactive Taxation, 22 J Legal Stud 265, 280, 296-301 (1993). Members of the coalition may not be especially vulnerable, but some members of the group would be more vulnerable to retroactive taxation than others. For example, those with very little property may not find it rational to organize resistance, but they can free ride on the rational resistance efforts of those with more to lose. Id. 
to form a corporation or LLC, but it was once costly. Corporation promoters needed to obtain a charter by act of legislature. ${ }^{24} \mathrm{Ob}$ taining such an act often involved costly bribes. ${ }^{25}$ The effort to liberalize chartering may well have been led by wealthy individuals_they were the ones paying bribes after all-but their efforts led to widespread availability of legal entities to promoters of modest means. Uniform access means greater access for those who previously had access but much greater access for those who previously had no access at all.

The same dynamic operates in the construction of private legal schemes. For example, when firms engage in mass contracting, their tendency to use similar contracts across many customers forces them to treat customers equally. Firms often write terms in a way that attracts the informed customers. This benefits the most ignorant customers, who cannot or will not negotiate for better terms or comparison shop. ${ }^{26}$ Ignorant or constrained customers may get a worse deal if the firms can offer different terms or price discriminate.

Yet vulnerable subjects can also subsidize strong ones. ${ }^{27} \mathrm{As}$ Professors Omri Ben-Shahar and Ariel Porat write for this Symposium:

If weak consumers are the recipients of a cross-subsidy under a uniform price regime, they could lose it if prices are personalized and might even be priced out. The culprit for this problem is the personalization of prices. As long as prices are uniform, the personalization of the protection itself does not necessarily hurt the weakest consumers. On the contrary, if weak consumers are the recipients of higher than average personalized protection, the cross-subsidy embodied in a uniform price would be bolstered. ${ }^{28}$

24 See Howard Bodenhorn, Bank Chartering and Political Corruption in Antebellum New York: Free Banking as Reform, in Edward L. Glaeser and Claudia Goldin, eds, Corruption and Reform: Lessons from America's Economic History 231, 233 (Chicago 2006).

25 See id at 235.

26 See Alan Schwartz and Louis L. Wilde, Intervening in Markets on the Basis of Imperfect Information: A Legal and Economic Analysis, 127 U Pa L Rev 630, 638-39 (1979).

27 See Omri Ben-Shahar, The Paradox of Access Justice, and Its Application to Mandatory Arbitration, 83 U Chi L Rev 1755, 1804-05 (2016) (discussing how lower-income consumers bear costs of access to the courts); Omri Ben-Shahar and Eric A. Posner, The Right to Withdraw in Contract Law, 40 J Legal Stud 115, 128, 144-45 (2011) (arguing that a mandatory right to return a purchase requires those who would prefer to forgo that right in exchange for a discounted price to "cross-subsidize other buyers").

28 Ben-Shahar and Porat, 86 U Chi L Rev at 273 (cited in note 1). 
Evaluating this cross-subsidy in light of public policy goals requires some knowledge of who is subsidizing whom.

Nor does formal equality optimize incentives. A tort law that holds talented individuals to a higher standard of conduct may encourage them to use their talents to a greater degree in order to avoid liability, just as a tort law that imposes higher penalties on individuals less able to take appropriate care in a risky activity discourages them from participating in that activity. Just as insurance can encourage better behavior by tailoring premiums to risk, law can improve incentives when tailored to individuals.

\section{B. Knowledge of Subjects}

In order to personalize law, lawmakers must be able to acquire and process granular information about individuals and groups. Until recently, wide-scale surveillance and data processing seemed technologically unfeasible. However, trends in data gathering and analysis suggest that well-resourced lawmakers may soon have the technical ability to link directives to highly particular individual traits. Increasingly, the most salient limitation to personalization may be not the ability to know subjects but instead the normative appropriateness of gathering and using vast sums of data.

When it is technically feasible and normatively acceptable to gather and use granular data concerning individuals, personalized law promises to better link directives with capacities and needs. If lawmakers could assess drivers' capabilities-under certain conditions and on certain stretches of road-they could craft a personalized speed limit reflective of those capabilities. If lawmakers could figure out why a trader wants to place a large order-to manipulate the market or to offset a major increase in farming capacity - they could modify commodity futures position limits accordingly. Conversely, if it is too costly to get and use personal data, or if privacy concerns bar this strategy, then the only alternative is impersonal law.

Many of the examples in this Essay ask about the trade-off between ex ante impersonal rules and ex ante personalized rules: whether the speed limit should tell everyone the same number or whether the dashboards should dictate different speeds to different drivers. But the rise of personalized ex ante law can also come at the expense of ex post personalized law, and this transition is also a function of knowledge. 
Ex ante personalized law gives specific, personalized mandates ahead of action, such as a dashboard speed limit. Ex post personalized law takes account of personal characteristics but only after an event has occurred or litigation has commenced. ${ }^{29}$ Legal standards such as the "reasonable person" standard, which factfinders apply to specific circumstances, have always involved a degree of personalization ex post. ${ }^{30}$ The new movement to personalization is largely about moving personalization forward in time-giving more granular guidance on what legal directive would have been implemented through open or vague standards later.

Higher levels of ex ante knowledge allow higher levels of ex ante personalization. We can create a personalized speed limit in advance of driving only if we know important features about the driver at that time. If lawmakers lack that knowledge, they may acquire it through individualized factfinding in adjudication. As generalized information acquisition and analysis become cheaper, it becomes feasible to do more of our personalization on the front end in ways that strike us as utterly new but are really extensions of existing practices.

Framing personalization questions in the ex ante/ex post literature allows new perspectives on the knowledge question. If it is costly to acquire information, it is generally better to pay for it ex post, only when it is needed. ${ }^{31}$ However, the amortized cost of the information falls if it can be used in many transactions, with and without the same subjects. Pre-accident assessment of a driver's capacities allows the lawmaker to personalize mandates

29 See Casey and Niblett, 92 Ind L J at 1408-09 (cited in note 5).

30 See id at 1407 (explaining that, with standards, "[t]he exact content of the law comes after an individual acts, as judges and other adjudicators determine whether the individual's specific behavior in a particular context violates the standard").

31 This point has been made with respect to contract drafting. See Richard A. Posner, The Law and Economics of Contract Interpretation, 83 Tex L Rev 1581, 1582, 1609-11 (2005) (explaining that parties may purposefully leave some contract terms ambiguous due to high information costs); Robert E. Scott and George G. Triantis, Anticipating Litigation in Contract Design, 115 Yale L J 814, 835-39 (2006) (discussing the tradeoffs between front- and back-end costs when writing contracts); Steven Shavell, On the Writing and the Interpretation of Contracts, $22 \mathrm{~J}$ L Econ \& Org 289, 297-98 (2006) ("It is assumed that parties write the contract with highest expected value, that is, the contract maximizes the expected value of the interpreted contract minus the writing costs."). See also Albert Choi and George Triantis, Completing Contracts in the Shadow of Costly Verification, 37 J Legal Stud 503, 520-23 (2008) (discussing the trade-off between investment costs and litigation costs). One cost of drafting contracts is learning enough to write more complete terms. 
for every drive the driver takes-lowering the per-use cost to potentially far lower than the cost of just acquiring this information in connection with a tort suit.

Relatedly, we should not assume that all improvements in information technology push in favor of ex ante personalization; some such improvements will lead to greater personalization, but predominantly of the ex post variety. Improved information systems may make it easier for courts to verify information that was previously observable only by the parties. When information is observable but not verifiable, it is difficult to personalize ex post. If new information technology increases verifiability, it will increase the viability of judicial personalization after the fact, causing much of the increase in personalization to express itself in the low-tech, ex post variety familiar to lawyers.

For example, consider the canonical category of an observable but not verifiable contract term: product quality. ${ }^{32} \mathrm{~A}$ buyer may be able to observe the quality of the goods or services she buysthe buyer has expert knowledge and taste, or perhaps the quality becomes obvious to any repeat customer-but these subtle cues may be challenging to communicate to a court. A driver observes that her car is of low quality by feeling its sometimes slow acceleration and paying for its greater than average maintenance costs, but it is hard for her to show that low quality to a court: Perhaps the car works fine the one day it is judicially examined. And the factfinder may be unsure whether the higher maintenance costs are because the car is a lemon or because the driver herself is a reckless operator. Car quality is easily observable but not easily verifiable. Terms warranting car quality are less effective as a result.

Improved data-gathering technology may make warranty terms more effective by improving verification. Suppose a car or cell phone logs the driver's use of the car-it may be easier for her to show that she drives only at typical speeds or only on typically smooth roads, making less debatable the cause of the car's problems. If the car or user's cell phone record noise levels, it will be easier to demonstrate to the factfinder that a growling noise is typical (even if the car isn't so loud when examined by the court).

32 See Oliver Hart, Firms, Contracts and Financial Structure 37-38 n 15 (Oxford 1995); Lisa Bernstein, Private Commercial Law in the Cotton Industry: Creating Cooperation through Rules, Norms, and Institutions, 99 Mich L Rev 1724, 1741 (2001). See also Robert Scott, The Law and Economics of Incomplete Contracts, 2 Ann Rev L \& Soc Sci 279, 286-87 (2006). 
Passive data gathering makes it more feasible to adjudicate quality terms ex post, allowing parties to substitute away from the alternative, inflexible, and impersonal ex ante contractual proxies for quality (such as warranties that cover a precise list of repairs for a precise period of time).

Let us take the warranty notion one step further. Some warranties of quality are deeply personalized. Take the warranty of fitness for purpose, whether express or implied. ${ }^{33}$ A warranty of fitness for purpose is an assurance of quality that is personalized to the user. A typical widget buyer may need one level of quality, while this buyer may need an altogether different-and higherlevel given her intended purpose.

Personalized warranties face a double verification problem: the court must detect both the quality level and the unique needs of the buyer. ${ }^{34}$ When the buyer complains that the widget is not fit for its purpose, how can the court confirm the buyer's purpose? How can the court reject claims by buyers who have fabricated a special purpose after the fact? Technological innovations in recordkeeping may help with this verification task. The buyer's factory (or even the widgets themselves) may keep records of the buyer's pattern of widget use-making clear whether this widget was used as past widgets were and whether the buyer really did have a different pattern of use from other customers. It will be easier to spot buyers whose widgets failed as a result of postpurchase changes in the buyer's business rather than as a result of pre-existing purposes. The seller's knowledge of the buyer's purpose may also be indirectly proven through ubiquitous data gathering. If we can gather the use pattern of all the seller's customers, we may discover that this seller's clientele overwhelmingly uses the widget in a particular way, supporting or undermining the seller's purported ignorance of the plaintiff's purpose.

The warranty of fitness for purpose is a personalized ex post contract term, and it is one that many parties have opted away from using. ${ }^{35}$ Yet improvements in verification technology may make it cheaper and more accurate to use, perhaps resuscitating an entire domain of contract law focused on ex post personalization.

\footnotetext{
33 See UCC $\S 2-315$.

34 Actually, the problem has a third aspect: the court must verify that the seller had reason to know the buyer's unique needs. The seller's knowledge may have been observed by the parties, but it is not easy to prove to a court what exactly was said in negotiations.

35 Indeed, it is customary practice for sellers to disclaim the implied warranty of fitness for purpose to the maximum extent permitted.
} 
Outside of contract, information technology innovations will lower ex post verification costs in tort, with resultant reductions in ex ante regulation and bureaucracy: things that were previously seen by parties or known only in an intuitive way may now be recorded in formats that are easy to share with the court. For example, ubiquitous smart watches with health monitors will be able to inform medical malpractice and toxic tort suits by serving to substantiate the parties' claim that the plaintiff was (or wasn't) in generally good health before the defendant's action. Matching a remedy to a tort victim's preexisting health has always been a form of ex post personalization in the law, but information technology will make this easier and more precise.

The fruit of this data is harvested only at the time of litigation, and it may reduce the pressure to craft front-end rules built to give similar results. If we know that once-healthy plaintiffs will be fully compensated ex post, we can work less hard to craft ex ante prophylactic safety rules for doctors and polluting factoriespotential tortfeasors can be better trusted to manage their own risks knowing they will generally internalize the costs. At present, many rules and procedures, from workplace safety laws to Food and Drug Administration approvals, may reflect a fear that the legal system will undercompensate plaintiffs who cannot prove their personalized injury; alternatively, rigid ex ante procedures may serve to protect defendants from overly generous compensation to plaintiffs who can fake greater than average desert. ${ }^{36}$ Either way, complex ex ante rules may prove less important, and can be less detailed, if ex post legal personalization is improved through better data gathering and processing.

Criminal law, too, may experience much of its personalization ex post. Professor Deborah Denno describes in her essay how improvements in neuroscience may allow courts to produce more just results for particular criminal defendants. Customizing criminal liability and punishment to particular brains is a clear case of personalization, but no one will imagine that this can be done in advance using the futuristic microdirectives that Professors Anthony Casey and Anthony Niblett predict. ${ }^{37}$ Instead, criminal

36 Insofar as potential tortfeasors adopt their own checklists, procedures, and recordkeeping in order to protect themselves against outsized, impersonal liability-and insofar as ex post personalization of liability reduces the need for these procedures-greater personalization of public law can reduce the need for private legalism.

37 Compare Denno, 86 U Chi L Rev at 370-80 (cited in note 1) (advocating for a more personalized approach to criminal law that takes into account individual neuroscientific 
laws of general application will govern and direct everyone, but some individuals will be subject to different consequences when they transgress. These different consequences will emerge from courts' verification of brain states and probably also from superior verification of lifestyle factors previously detected only impressionistically. A defendant's cell phone may keep good records of her travels and social network-powerfully confirming or disconfirming an incomplete psychological evaluation.

Conversely, it is possible that the new forms of information available will be of little help to courts. Perhaps the kinds of statistical relationships latent in big data cannot be usefully evaluated by judges or juries. Then the proportion of observable but not verifiable information may rise as parties acquire data to which courts are insensitive. That would lead to greater pressure for precise ex ante personalization. Ironically, algorithmic law is more likely to be prominent in our daily lives if it is baffling for nonexperts. If the legally relevant insights of big data can be communicated to laypeople, it will be easier to harvest them through traditional judicial processes rather than pervasive contractual and administrative directives.

\section{Knowledge of Law}

There are usually good reasons to let legal subjects know the content of the law. Legal knowledge is intrinsically valuable and instrumentally a precondition to accountability. If laws are illegible, subjects may find it difficult to object to them. In contractual settings, individuals may assent to complex but unfair or inefficient contracts. In public legal settings, voters may tolerate lousy laws (and lousy lawmakers) if they cannot easily understand the law.

Just as equality can be divided into formal equality and practical equality, knowledge of the law can be subdivided too, with personalization arguably increasing one conception of legal knowledge at the expense of the other.

The great advantage of personalized law is that it may be better at guiding and informing individuals about their obligations. When technology permits microdirectives, lawmakers can give certainty directly to individuals, instructing them on the law's

evidence), with Casey and Niblett, 92 Ind L J at 1410-12 (cited in note 5) (describing how technology might facilitate the emergence of microdirectives: highly personalized and specific legal directives transmitted to individuals before they act). 
content given their exact circumstances. Casey and Niblett imagine a world of specific and live guidance:

[A] specific microdirective is selected and communicated to a particular driver (perhaps on a dashboard display) as a precise speed for the specific conditions she faces. For example, a microdirective might provide a speed limit of 51.2 miles per hour for a particular driver with twelve years of experience on a rainy Tuesday at 3:27 p.m. ${ }^{38}$

With a dashboard speed limiter, drivers have complete certainty about their obligations at a given time. Live, personalized directives inform subjects better than constant, free legal advice.

Even lower-tech personalization promises to guide subjects before and during action. Ben-Shahar and Porat describe how linking negligence law to characteristics of individuals may give them a more accurate self-assessment of how the law will treat them than would a vague legal standard. ${ }^{39}$ Individuals may have greater certainty under a personalized tort law keyed to what is reasonable for them because they know whether they are unusually capable or incapable of safely performing certain tasks. Construction contractors and parties to financial derivatives already use ongoing quasi adjudicators to specify vague contractual terms on an ongoing basis. ${ }^{40}$ Personalization allows subjects to act lawfully without as much guesswork.

Yet there are also knowledge costs to personalization. Impersonal laws are better for subject-to-subject legal education. If laws are impersonal, then individuals can learn from one another about the law. If Mary complains about getting a ticket for speeding at 66 miles per hour, Todd learns something about the law in action because that same speed limit applies to him. Not only can Todd learn from the anecdotes directly related to him, he can also learn from norms and culture that develop in light of myriad encounters with the law. If no one in Todd's neighborhood parks their cars on the sidewalk or if passengers in the car express concern when Todd edges his car up over the curb, Todd may infer that the law in his community disallows sidewalk parking.

38 Casey and Niblett, 92 Ind L J at 1404 (cited in note 5).

39 Ben-Shahar and Porat, 91 NYU L Rev at 677 (cited in note 5) ("Personalized standards . . require no learning, as much as they harness information injurers already have about themselves.").

40 See Verstein, $55 \mathrm{Wm}$ \& Mary L Rev at 1912-14 (cited in note 6) (describing the quasi-adjudicative role that the International Swaps and Derivatives Association plays). 
This learning does not work as well if law is personalized. If cars whiz by Todd on the highway, he cannot infer that the speed limit is higher than he thought because the other drivers may be authorized to drive at a faster speed. If Todd's friends are lighthearted about even large online purchases, remarking how easy it is to return items, Todd should still be cautious before trading. Their history of easy returns may be because of different contract terms than those he will get. Their past performance is no predictor of $h$ is future results.

Subject-to-subject learning also goes the other direction. Todd's experiences with the law allow him to predict Mary's legal rights and constraints. This knowledge allows Todd to give Mary amateur legal advice, but it also allows him to coordinate his interactions with her. If he hires her to deliver a package, he has some sense of her legal constraints-he need not wonder if she will be waylaid by police for driving at the speed necessary to make the delivery. ${ }^{41}$ If Todd competes with Mary for business opportunities, he need not wonder whether Mary can lawfully drive much faster than him to meet the prospective client or chase the proverbial ambulance.

These interpersonal considerations are important even in impersonal settings. For example, commodities traders care deeply about whether other traders are subject to the same rules. They take positions and implement trading strategies with some sense of how other traders might behave. They must tread lightly if the position limits of other traders are variable and, thus, unknown. For example, in 1989, soy bean traders were caught unaware when a major trader secured an exemption from normal trading limits and promptly cornered the markets. ${ }^{42}$ Personalized law leads to potentially higher risk and learning costs in interpersonal interactions, even in settings in which standardization and predictable rules are prized.

Impersonal law allows knowledge through orthodox learning efforts, such as looking up cases and statutes. It is easier to look

41 These differences also go to equality, as discussed earlier. Does it stigmatize Mary, or harm her employment prospects, if she has lessened driving rights relative to Todd? Does it stigmatize her if she has superior return rights for online purchases, reflecting the state's determination that she is more likely to make purchasing and contracting errors? Does it undermine the legitimacy of market outcomes if competitors play by different rules?

42 See Robert A. Rosenblatt, U.S. Agency Forced Ferruzzi to Trim Soybean Holdings (LA Times, July 21, 1989), archived at http://perma.cc/9DEU-TFB9 (noting that new rules applied only to Ferruzzi, which had a special exemption). 
at case law if the myriad disputes all contribute to precedent on the same law. If different mandates apply to different people, it becomes easier to distinguish cases and harder to build a common body of law on a subject.

By disregarding numerous contextual factors, impersonal law is also somewhat easier to record as a public text. At least in theory, an attentive person can learn the law by looking it up. Although statutes and administrative rules are not easy to read, they are natural language, follow conventional rules of English grammar, and are of a finite length. An intelligent person can learn a lot about a law's operation by looking at its official text.

By contrast, personalized law may be recordable only as an algorithm or a set of interrelated rules, perhaps cross-referencing a data set. It may require new skills to understand, such as data science or computer programming. ${ }^{43}$ Even legislators may be unable to understand what they have voted on. The complexity of these rules may make them incomprehensible to subjects and raise the cost of legal certainty. In other cases, the law itself may be fashioned only in broad terms, with the personalization operationalized outside the contract, statute, or rule. ${ }^{44}$

It is true that microdirectives would obviate the need to look up the law to resolve any particular case, but one might want to look up the law for a reason other than a particular dispute. One might want to understand how broad classes of cases work or to see the law's entire sweep so as to know whether it is a good law.

To change directions somewhat, let us note that legal knowledge (in any conception) is not an unalloyed good. When law is public, subjects can behave strategically to exploit it. Personalized law may be more desirable when the risk of strategic behavior is high, so long as the personalized law is sufficiently granular and robust to avoid new forms of strategic behavior. Microdirectives can give specific mandates without empowering the subject to seek out loopholes or vulnerabilities.

43 My claim is not that these skills are harder to learn than the legal skills needed to properly learn impersonal law. I simply mean that these skills are not currently deemed part of the ordinary process of learning the law. We have an inchoate sense of what counts as legal knowledge, and that body of knowledge does not currently include these skills. It may be desirable to abandon the old conception of legal knowledge, or to modify it, but it remains true that a step toward personalized law is at odds with an orthodox conception of legal knowledge.

44 See Casey and Niblett, 92 Ind L J at 1410 (cited in note 5) ("The lawmaker can set a broad objective, which might look like a standard. But the predictive technology will take the standard and engineer a vast catalog of context-specific rules for every scenario.”). 
As for accountability, the complexity of personalized law is also a form of ultimate transparency. If law takes account of twenty factors and assigns each certain coefficients, subjects can more precisely determine whether the lawmaker is giving appropriate weight to the relevant considerations. If lawmakers include, say, race as one factor in the law's contours, subjects can immediately object if they think this should not be part of the law. Such objections are harder if an impersonal law weighs but does not cite the suspect factor. Yet it can be hard to eliminate bias from such systems, and superficial efforts to do so may actually exacerbate the problem. ${ }^{45}$

\section{WHEN SHOULD LAW PRIVATIZE?}

Regardless of whether speed limits should be personal or impersonal, should they be created by the Department of Transportation or by Google? Regardless of whether position limits should be personal or impersonal, should they be created by the CFTC or by the commodities exchanges? A substantial literature discusses the comparative merits of government regulation, private regulation, and private ordering.

This Part presents a quick summary of the literature on privatized law. As with personalization, we can view the choice as a function of several considerations. Here, the three considerations are: scope of legitimate power, incentives, and knowledge.

\section{A. Scope of Legitimate Power}

Private regulation ultimately derives its authority from consent. If individuals meaningfully agree to a system of regulation, we are often content to pronounce that system legitimate as to them. Consent faces limitations, of course. For one thing, the consent must be meaningful rather than the result of error or duress. Moreover, some rights cannot be surrendered by contract and so cannot be surrendered through regulations secured by mere agreement. Overall, voluntary systems secure a presumptive legitimacy, which may be bounded by concern for substantive or procedural unconscionability.

An assent-based system of regulation faces strong practical limits. If assent must be secured, then the fixed cost of securing assent must be paid many times over. It is therefore suitable only

45 See Talia B. Gillis and Jann L. Spiess, Big Data and Discrimination, 86 U Chi L Rev 459, 467-73 (2019) (discussing how input restrictions may worsen discrimination). 
when the costs of contracting are low or the benefits from the deal are particularly high. ${ }^{46}$

More importantly, it may sometimes prove difficult to secure assent. Some potential subjects of regulation may resist participation unless the rules can be made favorable to their preferred conduct. But what is incentive-compatible for a given agent may not be the best rule for the group.

Public law secures its legitimacy not through actual consent but through some foundation explicable in political philosophy. ${ }^{47}$ While the details of this foundation may be contested, we usually hold state action to political, procedural, and substantive standards. Politically, the current practices of the state must be traceable to current politics in a way that grounds law in the will of its subjects. Procedurally, states must regularize their use of power. For example, certain rights may be compromised but only by law enforcement officials after a suitable trial. Substantively, states are constrained by their constitutions and perhaps other features of justice to protect certain rights and interests.

These two different legitimacy structures may bear on the appropriateness of privatizing law. Consent-based legitimacy is on stronger ground in regulating optional behavior by sophisticated individuals engaged in actual contracting. For example, commodity futures traders are sophisticated actors who meet to exchange contracts for future delivery. To some degree, if they disagree with any given trading rule, they can trade at another venue. The case for private regulation by commodities exchanges is therefore strong.

In some ways, the assent-based case is even stronger than the public law case for stock and commodities regulation. Many traders are not located in the United States. When such traders trade on a purely electronic exchange, the jurisdictional case for American law is debatable. ${ }^{48}$ Is federal law responsive enough to make its force legitimate to overseas traders? No such debate is

46 See Joshua Fairfield, The Cost of Consent: Optimal Standardization in the Law of Contract, 58 Emory L J 1401, 1411 (2009) (noting that, if consent is inexpensive, parties will achieve an efficient outcome, but if consent is expensive, parties will achieve inefficient outcomes).

47 For a discussion of consent-based and other theories of legitimacy, see Fabienne Peter, Political Legitimacy (Stanford Encyclopedia of Philosophy, Apr 24, 2017), archived at http://perma.cc/R48M-EYD7.

48 To be clear, it is not debatable as a matter of actual law. The link to a US exchange would clearly suffice to establish jurisdiction. 
necessary if the traders have actually consented in contract to the rules of the exchange.

Automotive speed limits are less readily amenable to consent-based legitimacy. If there is only one road to one's house, one cannot realistically decline the terms of the relevant lawmaker. Conversely, the transaction cost of securing assent on every distant road, traveled just one time in an individual's life, could prove too high. Nor do we imagine it would be legitimate for private actors to coercively secure compliance. If the only way to stop excessive speeding on a private road is to imprison a person, we are unlikely to think that contractual assent will suffice to justify private imprisonment. By contrast, the state's distinctive role in regulating safe use of public thoroughfares makes its coercive enforcement quite plausible.

The scope of assent-based regulation can be expanded or reduced through government action. Private regulators are better able to impose their rules if they have market power. Otherwise, their subjects can substitute away rather than assent. With market power, their subjects may be forced to accept the private regulations. The scope of assent-based regulation can thereby expand as market power does. And market power can expand or contract depending on the state's stance toward the private regulator.

For example, stock exchanges have sometimes sought to ban their members from trading on other exchanges or to ban listed companies from being traded in other venues. ${ }^{49}$ These rules undermine the ability of other venues to compete for trading volume, and so they make it easier for the rulemaking exchange to condition its services on the acceptance of its directives. ${ }^{50}$ The state decision of whether to enforce or invalidate such exclusivity clauses can prove decisive for the power of private regulators.

Aside from merely tolerating these clauses, the government can do even more to protect the competitive position of private lawmakers. For example, the trading and price data generated by exchanges is valuable and allows off-exchange traders to free ride. If exchanges have intellectual property rights in this information,

49 For a description of one such attempt, see J. Harold Mulherin, Jeffry M. Netter, and James A. Overdahl, Prices Are Property: The Organization of Financial Exchanges from a Transaction Cost Perspective, 34 J L \& Econ 591, 608-09 (1991).

50 See id at 604 (explaining that courts recognize exchanges' rules as voluntarily accepted and do not consider rules prohibiting trading with nonmembers to unlawfully restrict trade). 
or if they can keep the prices secret as a matter of practice, then the trading venue is in a strong position to condition access upon rule adherence. ${ }^{51}$

Yet market power can be used for reasons other than optimal rulemaking. Indeed, market power can permit private actors the freedom to neglect the quality of the rules they produce if they are insulated from competition from other lawmakers.52 For these reasons, courts and legislatures have sometimes taken a skeptical view of each of the market-power-increasing practices described in the previous two paragraphs. ${ }^{53}$

Getting a sense of the wisdom of market power in a given case requires a look at incentives, to which I now turn.

\section{B. Incentives}

Ideally, public actors are motivated by public interest concerns and are constrained by democratic forces when they diverge from the public interest. By contrast, the public choice literature examines the private incentives of public actors. ${ }^{54}$ Laws that impose concentrated costs or benefits may spur interest groups to organize and demand regulation suitable to their needs rather

51 See id at 625-26 ("By allowing the exchanges to establish rights to such property, [courts] enabled the exchanges to reap the gains from technological innovation and thereby promoted the growth of exchanges."). See also Board of Trade of the City of Chicago v Christie Grain \& Stock Co, 198 US 236, 250-51 (1905) (recognizing an exchange's property right in price information and right to block transfer to other trading venues).

52 See Stephen Craig Pirrong, The Self-Regulation of Commodity Exchanges: The Case of Market Manipulation, 38 J L \& Econ 141, 149-57 (1995) (criticizing optimistic views of market self-regulation).

53 See, for example, Silver v New York Stock Exchange, 373 US 341, 364 (1963) ("Congress in effecting a scheme of self-regulation designed to insure fair dealing cannot be thought to have sanctioned and protected self-regulative activity when carried out in a fundamentally unfair manner."); Thill Securities Corp v New York Stock Exchange, 433 F2d 264, 272 (7th Cir 1970) (noting that private exchange commissions' principal responsibility for regulation comes from Congress's antitrust laws, not its own self-regulation doctrine); 17 CFR $\S \S 242.610,242.611$ (c) (guaranteeing reasonable access to trading price data and requiring brokers to route intermarket sweep orders wherever the price is best).

54 See, for example, Jerry Mashaw, Public Law and Public Choice: Critique and Rapprochement, in Daniel A. Farber and Anne Joseph O'Connell, eds, Research Handbook on Public Choice and Public Law 19, 20-25 (Edward Elgar 2010) (noting that public choice theory stands in stark contrast to "an idealized version of the democratic-bureaucratic process"). 
than the public's needs. ${ }^{55}$ Another perspective on government behavior emphasizes the personal incentives of individual officials. In a system like ours that emphasizes job security rather than career advancement, the incentives for any action, good or bad, may be muted.

Private actors operate with different incentives. When private actors internalize the benefits they create, we can expect vigorous action. Even large and complicated projects can be undertaken by raising funds in capital markets. If private actors can charge for high quality regulation and enforcement, we can expect high quality regulation and enforcement. This is the central claim of those who would emphasize the stock or commodities exchange as the optimal regulator. ${ }^{56}$

However, when private actors do not internalize the benefits they create, they may regulate suboptimally. ${ }^{57}$ For example, when regulations impose costs on third parties who are not in privity with the regulator, the regulator has little reason to take their well-being into account. 58

Moreover, even when all the relevant parties are privy to contracts with the regulator, the regulator may still take inefficient steps to extract surplus. For example, a monopolist may undersupply its product in order to charge more. In the regulatory context, the regulator may deprive certain parties of access to the regulated venue, or it may customize the rules to advantage favored clients. 59

\section{Knowledge}

One common argument in favor of private regulation is that the private actors may have greater knowledge and expertise

55 See Mancur Olson, The Logic of Collective Action: Public Goods and the Theory of Groups 9-11 (1965) (discussing how private companies employ effective lobbying to advance regulation and policy to benefit their respective products).

56 See, for example, Mahoney, $83 \mathrm{Va}$ L Rev at 1477 (cited in note 4) ("If stock markets face sufficient competition, then, restrictive rules will survive only to the extent they are efficient.").

57 See id at 1463. See also Pirrong, 38 J L \& Econ at 150-57 (cited in note 52) (arguing that exchanges lack incentives to prevent manipulation).

58 Relatedly, when the regulator imposes a benefit on third parties but is unable to charge effectively for it, the regulator may gain incentives to discontinue or malproduce the public good. See Gabriel Rauterberg and Andrew Verstein, Index Theory: The Law, Promise and Failure of Financial Indices, 30 Yale J Reg 1, 37 (2013).

59 See Mahoney, 83 Va L Rev at 1463 (cited in note 4). 
than administrative agencies or Congress. ${ }^{60}$ This is often local knowledge, learned on the ground by practicing the regulated subject as a career. Governmental actors can acquire this information only dimly, by drawing it out of the regulated subjects.

Yet even if government knowledge of an industry may be inferior to the participants in that industry, the government has access to many industries. Secondhand knowledge of many domains may sometimes matter more than firsthand knowledge of any one domain. Still, the relative importance of global knowledge is not itself a justification for government regulation rather than private regulation because the government can of course share its findings with the world. For example, the government researches numerous factors relevant to commodity production, but it then releases that information to the public-for private individuals to use however they like.

The case for government regulation is therefore stronger when global knowledge is required and when the government faces limitations on its ability to share the knowledge. The government may acquire proprietary information about given firms, which would not be available to any private actor but would be inappropriate to share with competitors and customers. For example, the government demands extensive information about banks, but disclosing that information could lead to bank runs. As another example, the government solicits information about industrial companies, but disclosing that information could facilitate collusion by erstwhile competitors. It is sometimes better for the government to retain the global informational advantage and regulate in light of that information.

\section{How Does Privatization Bear on PeRsonalization?}

Should directives be personal or impersonal? Should they be governmental or private? I have explored these questions in isolation, but I now consider one in light of the other. In this Part, I take for granted that the facts or concerns implicated would naturally call for personalized law. Can we conclude anything about the appropriate author of the private law from the utility of personalized law alone? In this Part, I explore a number of possible

60 See, for example, Gadinis and Jackson, 80 S Cal L Rev at 1253, 1298 (cited in note 4) ("There are strong arguments in favor of permitting exchanges to set their own trading rules, as they possess higher expertise and are better placed to understand the demands of the market."). 
implications. While there are many threads in the discussion below, one theme emerges: the move to personalized law is often best taken by private lawmakers. Thus, as both a descriptive and normative matter, a future that makes the best use of personalized law should involve a diminished role for state directives.

\section{A. Kaldor-Hicks Personalization}

Personalized law may involve giving some individuals tougher treatment than they would get under an impersonal law. These individuals are likely to resist the imposition of the directive. Sometimes this will suggest the importance of state regulation, which can be imposed without assent. Yet the victims of legal change often form effective lobbying groups. Moreover, the sort of government able to resist NIMBY interests may also be the sort of government that generally undercounts the cost of legal change to those subject to the new law. ${ }^{61}$ The sort of government with the grit to impose Kaldor-Hicks efficient ${ }^{62}$ personalization may also be the sort that settles for inefficient personalization.

Private regulation will often provide a better framework for securing compliance and evaluating the appropriateness of the personalization. Consider a modification to the commodities position limits rules that would grant Alpha greater freedom to buy futures than anyone else, in recognition of the fact that Alpha is clearly a farmer with a legitimate need to hedge. Conversely, the exchange also considers a rule that would impose a more stringent position limit on Beta, surmising that Beta owns no physical commodities and is therefore more likely (at the margin) to default on any futures she buys.

If these are wise changes that actually create value, then Alpha should be willing to pay more for her privilege-enough to compensate any objectors to the change. Beta may not like having more limits, but the exchange can offer Beta a discount owing to her different status. The discount can reflect the reduced risk (paid for by Delta and other traders who are happy about the reduced risk). The only trader who would be displeased by such a

61 Consider James C. Scott, Seeing Like a State: How Certain Schemes to Improve the Human Condition Have Failed (Yale 1998).

62 See Jules L. Coleman, Efficiency, Utility, and Wealth Maximization, 8 Hofstra L $\operatorname{Rev} 509,513$ (1980) (“One state of affairs $(E$ ') is Kaldor-Hicks efficient to another $(E)$ if and only if those whose welfare increases in the move from $E$ to $E$ ' could fully compensate those whose welfare diminishes with a net gain in welfare."). 
discount is one who really planned to impose risks on the exchange through her large positions-and the exchange can take comfort that the failure to strike a deal with such a trader is a good sign.

The gains from personalization rely not just on the regulator's knowledge of the subject but also on the subjects' knowledge of the regulator. If information about the private regulator is limited, it might grant Beta an inefficient privilege in exchange for a side payment. Such a risk is present for impersonal law but is perhaps smaller because Beta's privilege would have to take the form of an exemption from a general law, rather than just another twist in the road for a complex personalized law. The same is true for personalized laws that impose costs on third parties.

When these risks are high, private lawmaking may be comparatively less appropriate for personalization. Still, we should not overstate our ability to locate cases in which private lawmakers are exploiting their position such that the state would do better. ${ }^{6}$

\section{B. Secret Law}

Professors Larry Ribstein and Bruce Kobayashi have evaluated the incentives of private actors to produce excellent laws. ${ }^{6}$ They juxtapose two means of monetizing the lawmaking. If intellectual property rights are available, then private actors can internalize many of the benefits of their creation by charging users for a license to use the laws. ${ }^{65}$ If such protection is unavailable, they can monetize the laws only indirectly. ${ }^{66}$ For example, members of a bar association can monetize laws by including suboptimal terms that drive demand for legal services. ${ }^{67}$ For Ribstein and

63 See Mahoney 83 Va L Rev at 1476 (cited in note 4) ("There is no sharp contrast between exchanges and governmental regulators where restrictive rules are concerned; each has vacillated from time to time between support for and opposition to restrictive rules.").

64 Bruce H. Kobayashi and Larry E. Ribstein, Law as Product and Byproduct, 9 J L Econ \& Pol 521, 523-26 (2013) ("Private lawmakers could have stronger and betteraligned incentives to produce efficient laws than do public legislators.").

65 See id at $534-36$.

66 See id at 537 (noting that, without effective intellectual property rights, not all jurisdictions will pay the private law producer a licensing fee when it adopts the producer's set of provisions).

67 Id at 539-40. 
Kobayashi, this result is a defect that proves we ought to grant IP rights in laws. 68

Their analysis depends on the plausible assumption that law must be public and, therefore, feasibly copied. Yet personalized law may involve complex algorithms that may be hard to comprehend and reproduce without access to data.

We use personalized law when its benefits are sufficient to offset our concerns about simplistically legible public laws. In these cases, we could take the first step toward protecting legal innovations without IP law. If lawmakers construct an excellent legal rule and supplement it with excellent data, it may be difficult for competitors to recreate it based upon what is available in the public domain. We could then count on better private law making without having to construct an IP regime for laws.

Consider a few examples. Professors Lior Strahilevitz and Porat suggest that contract default rules be derived from the preferences of one million "guinea pig" subjects, intended to represent the population as a whole. ${ }^{69}$ The proposal imagines that the Consumer Financial Protection Bureau or an industry consortium might finance and conduct the surveys, ${ }^{70}$ but coordinated efforts may lead to disagreement about what sorts of questions are of interest. Companies wishing to clarify terms idiosyncratic to their industry will find little support from the broader coalition. They may finance their own supplemental surveys, ${ }^{71}$ but they may be reluctant if other firms can free ride on the information generated. This problem can be avoided if the survey results can be kept for use only by the surveying firm or consortium ${ }^{72}$ (subject to appropriate transparency for consumers who wish to understand the contractual obligations they are assuming).

Consider also the speed limit example. If Google designed an optimal system for speed limits that minimized accidents while reducing commutes, it would have a valuable service. However, its ability to sell the service to consumers, insurance companies,

68 See Kobayashi and Ribstein, 9 J L Econ \& Pol at 539 (cited in note 64) ("[L]aws drafted by private parties incentivized by property rights would be more likely to reflect firms' actual needs than byproduct laws, which are aimed at redistributing social wealth to the interest groups who drafted the laws.").

69 Porat and Strahilevitz, 112 Mich L Rev at 1450 (cited in note 5).

70 Id.

71 See Ian Ayres and Alan Schwartz, The No-Reading Problem in Consumer Contract Law, 66 Stan L Rev 545, 579-87 (2014) (proposing that individual firms survey their customers regarding contract term meanings).

72 See Porat and Strahilevitz, 112 Mich L Rev at 1454-56 (cited in note 5). 
or states would be limited by the threat of free riding. If laws are public and can be copied as a matter of principle, then competitors could largely extract the fruit of Google's labor. However, if we are tolerant of opaque speed limits (so long as we receive microdirectives and can audit the software if needed), then it will not be feasible for competitors to steal Google's secret sauce. Indeed, if the microdirective were delivered directly to a self-driving car rather than made legible to users, it would be difficult to even reverse engineer the law as code.

In principle, government actors could also take advantage of relative opacity of personalized laws as a substitute for intellectual property rights in laws. ${ }^{73}$ If one state invents a better personalized corporate law, it may be able to slow adoption by other states, and thus internalize the benefits of the innovation, if aspects of the law are not easily inferred from a public text. Any time the quality of law is at all dependent upon lawmakers' ability to internalize its benefits, the partial obscurity of personalized law may be a useful feature in improving the quality of law.

Nevertheless, the accountability norms for public actors make it less likely that personalized law algorithms will remain private for long. Altogether, personalized law is likely to arise in contexts in which private actors will be at a comparative advantage in pursuing the gains from legal innovation.

73 Personalization has other potential benefits in terms of secret public law. Professor Saul Levmore has described how retroactive law can reduce gamesmanship and strategic behavior. See Levmore, 22 J Legal Stud at 273-74 (cited in note 23). Professor Casey has described the comparable benefit of microdirectives in reducing gamesmanship while still allowing predictability and a measure of accountability. See Anthony J. Casey, The Short Happy Life of Rules and Standards, at 39:03-41:00 (Feb 21, 2017), online at http://www.youtube.com/watch?v=TnbRApMEumU (visited Aug 27, 2018) (Perma archive unavailable). Laws can be public at the level of their general mandate ("don't drive recklessly"), while the details of the algorithm remain out of sight.

Such a view breathes new life into an old debate in political theory: whether representatives should be trustees, who use their own judgment on behalf of constituents, or delegates, who just vote as their constituents would want them to. See Andrew Verstein, Trustee or Delegate? Understanding Representation to Illuminate Shareholder Governance and Regulatory Change, 9 Eur Co \& Financial L Rev 74, 76 (2012). In recent years, the delegate position has lost its luster. Sure, it made sense to send delegates at a time when telecommunications were rare and travel was long. But it is now possible to conduct electronic referenda on issues. If there is an appeal to the delegate, it seems like it is at risk of being replaced by an online plebiscite. To have representatives at all is to embrace the trustee model. Or so one might have thought apart from secret, personalized public law. However, with secret, personalized public law, general laws might be promulgated but the specific code retained by the government. A district's delegate would have access to the code and could engage in legal reform if the code does not represent the district's values, but the code itself would remain out of the hands of those who could use it strategically. 
C. Knowledge of Local Subjects

Granular information about subjects is essential to worthwhile personalized law. Endorsing personalized law means overcoming technical and normative obstacles to big-data personalization. Private law actors are better positioned to respond to both obstacles.

As we now know well, private actors have become leaders in mining their customers for data. By providing location-sensitive services, Google learns about its users' daily movements, preferences, and capacities. The same is true of stock exchanges, which observe individuals' trades simply in order to effectuate them. This local knowledge advantage is of highest value for personalized laws because of the economies of scope among service provision, monitoring, and directive-giving.

Consider a personalized speed limit, and imagine that it has been privately produced by Google. How will Google generate directives for individuals? It would have to monitor an individual's location through GPS, keep track of an individual's driving history, and combine these and other data based on some kind of risk prediction system. Yet these same links-such as live contact with the car's location-are also likely the means of delivering the mandate. Google will have to communicate the directive, either to the driver or the car (if it is self-driving). The same bilateral link is likely to serve both purposes. Google could introduce the government into the chain, with Google sharing the car's location with the Department of Transportation (DOT) and then communicating the DOT's mandate back to the driver, but these steps are redundant if Google is already dealing with the customer.

Consider next the normative case, in which private actors are better positioned to use the data available. The state's legitimate scope is ultimately tethered to its citizens' expectations, whether by electoral forces or its constitution. Americans are apprehensive about government acquisition and use of data but appear far more accepting of private gathering and use of information. ${ }^{74}$ Moreover, private lawmakers' scope of legitimate power is initially bounded only by consent, meaning that firms can use information even

74 See Kenneth Olmsted and Aaron Smith, Americans' Experiences with Data Security (Pew Research Center, Jan 26, 2017), archived at http://perma.cc/4JGN-ET4C (finding that Americans often trust private entities more than the federal government to protect their private information). 
when people are squeamish so long as they remain blithe in waiving privacy rights.

Keeping privately generated information in the hands of private lawmakers may reduce the chilling effect of using the information. When subjects' information is used to generate adverse legal consequences, subjects may be reluctant to share their information. Right now, most people blithely share their information with companies in connection with goods and services, but they might not do so if the government used that information aggressively to penalize or constrain them..$^{75}$ If information remains just with private actors, to use in making law related to their own products and services, the private costs of personalized law could be lower, and so voluntary participation may be greater.

The advantage of private actors is not unequivocal. When optimal personalization turns on global knowledge and this information cannot be shared with private actors, the government may be the appropriate personalizing body.

Still, when unshareable global knowledge is crucial, personalization is rarely the right policy anyway. When the government surveys hidden information about banks and deems it appropriate to act, the policy intervention is likely to be general. Recall that the Troubled Asset Relief Program (TARP) funding used to prop up the financial sector was distributed to many more banks than actually required the money. ${ }^{76}$ This was in order to prevent the TARP funding from creating a negative stigma for its users. In the cases in which the government cannot share the information, it will be because of the same problems that prevent the government from personalizing law in light of that information.

Moreover, "global" is a relative term. Market stability may require legal interventions (personal or otherwise) that take account of the actions of myriad traders. Yet much of this information is available to the stock exchange, and even more could be

75 See Niva Elkin-Koren and Michal S. Gal, The Chilling Effect of Governance-byData on Data Markets, 86 U Chi L Rev 403, 416-17 (2019) (presenting evidence suggesting that increased awareness of government surveillance prompts Americans to curb sensitive data usage). On the other hand, individuals might not discontinue data sharing. They might find the benefits of the services to still exceed the costs. Or a separating equilibrium might occur in which those who avoid information sharing are, by default, given the toughest treatment so that nearly everyone opts back into information sharing.

76 Goldman Sachs wanted to decline the TARP funding, in part because it contained limitations on bonus payments, but was cajoled into accepting. See Matt Taibbi, Secrets and Lies of the Bailout (Rolling Stone, Jan 4, 2013), archived at http://perma.cc/33ZV-X2UP. 
acquired. Personalization requires more than knowledge of a single investor, but it does not require anything more "global" than the exchange could learn from its own traders.

While the legitimate scope of action is often wider for the assent-based regime of private regulation than for government regulation, personalizing private regulation can still raise legitimacy objections. Even when consented to, personalized rules can feel, well, personal. Traders may feel that updated requirements reflect power dynamics within the exchange, with powerful traders able to force the exchange to change the rules to disadvantage less powerful traders. ${ }^{77}$ Consider one trader's statement about why he was willing to brazenly ignore a reduced position limit:

Yes. [The exchange official] called me. He said I have to get out some of my stuff[.] I ask him why? I mean. I don't understand. Why should I do that? I mean, when I'm losing half a million dollars nobody told me to get out, and now I'm trying to make a couple of bucks and they tell me to get out. ${ }^{78}$

The trader felt that the updated rules involved an unfair exercise of human discretion, a sentiment expressed by other small traders who have broken rules. Responsive position levels and accountability levels are a good thing, but the human element of the updating irks traders and makes the system seem less credible. Perhaps limits driven by big data and delivered in an impersonal fashion would allow greater personalization with greater legitimacy.

\section{CONCLUSION}

This Essay has examined the choice of optimal maker of personalized law. It teased out many of the considerations that bear on the choice, and it identified the many factors that favor private law in the context of personalized directives. Having made substantial progress on the question of what to personalize, we now have some purchase on who should personalize.

77 See, for example, Zimmerman v Chicago Board of Trade, 360 F3d 612, 614 (7th Cir 2004) ("The plaintiffs argue that the CBOT violated antitrust laws by adopting the [adjusted position limits], not for proper regulatory purposes but instead out of selfinterest and to protect a politically powerful member of the CBOT."); George Gunset, CBOT Chief Answers to Iowa Soybean Farmers (Chicago Tribune, July 22, 1989), archived at http://perma.cc/93L3-Q6Z8 (“'It looks to me like that you took sides on this,' said Ray Heck, a soybean farmer from Perry, Ia. 'It's highly unfair . . . to us. You say the major market participant was stubborn. It looks to me like you people were stubborn.”').

78 Saberi, 488 F3d at 1211. 
Many questions remain, including how. Stating that the optimal regulator is a private regulator does not tell us the mechanism by which private regulation is realized. In fact, there are numerous options: the state can tolerate private regulation as it arises, so long as it does not conflict with public law, or it can go further and honor private law even when inconsistent with public law; the state can let its subjects opt in or out of private regulation, or it can compel their accepting private lawmakers in the same way as it mandates insurance for drivers or registration with a self-regulatory organization for stock brokers. The right answer may depend on the domain. 